Check for updates

Cite this: RSC Adv., 2018, 8, 3051

Received 30th September 2017

Accepted 4th January 2018

DOI: 10.1039/c7ra10807a

rsc.li/rsc-advances

\section{Enhanced osteogenic activity of Ti alloy implants by modulating strontium configuration in their surface oxide layers}

\author{
Zhengjiang $X u, \dagger^{a}$ Huaifeng $L u, \dagger^{a b}$ Jian Lu, ${ }^{b}$ Chen Lv, ${ }^{b}$ Xiaobing Zhao*b \\ and Guocheng Wang (iD) *a
}

\begin{abstract}
To guarantee the long-term stability of an orthopaedic implant, non-degradable surface coatings with the ability to selectively release bioactive drugs or ions are especially desirable. In this study, $\mathrm{SrO}-\mathrm{TiO}_{2}$ composite coatings were deposited on the surface of $\mathrm{Ti}$ alloys, whose release behavior of bioactive $\mathrm{Sr}$ ions was modulated by the $\mathrm{Sr}$ configurations, either interstitial atoms in solid solution $\left(\mathrm{Ti}_{y} \mathrm{Sr}_{2-2 y} \mathrm{O}_{2}\right)$ or strontium titanate $\left(\mathrm{SrTiO}_{3}\right)$. A perfect linear relationship between the amount of the released $\mathrm{Sr}$ ions and the $\mathrm{Sr}$ content in the coating was observed. Among the $\mathrm{SrO}$-doped $\mathrm{TiO}_{2}$ coatings, the $20 \% \mathrm{SrO}-\mathrm{TiO}_{2}$ coating where $\mathrm{Sr}$ existed in both forms of $\mathrm{Ti}_{y} \mathrm{Sr}_{2-2 y} \mathrm{O}_{2}$ and $\mathrm{SrTiO}_{3}$ not only promoted proliferation of bone cells but also enhanced their osteogenic differentiation, which was proved to be related to its $\mathrm{Sr}$ release behavior. However, overdosing with $30 \% \mathrm{SrO}$ only resulted in one single $\mathrm{Sr}$ configuration $\left(\mathrm{SrTiO}_{3}\right)$ and an inferior osteogenic function. This study suggests that $\mathrm{Sr}$ configurations of both interstitial atoms of the solid solution and $\mathrm{SrTiO}_{3}$ can realize the selective release of $\mathrm{Sr}$, but they possibly have different effects on the biological functions and other properties including corrosion resistance.
\end{abstract}

\section{Introduction}

A variety of metal ions have been documented to be essential for the human body and widely used as therapeutic agents in the treatment of many types of diseases, such as anemia, bone, brain and neuron diseases. ${ }^{1-3}$ In bone tissue engineering, some metal ions, represented by strontium $(\mathrm{Sr}),{ }^{4} \mathrm{zinc}(\mathrm{Zn}),{ }^{5}$ magnesium $(\mathrm{Mg})^{6}$ etc. were proven to promote bone tissue regeneration and have been widely used in the field of therapeutic tissue engineering. One of the most important advantages of using metal ions is that it does not pose risks of decomposition or instability, which are intrinsic to some drugs and proteins., Among those ions reported to be essential for bone metabolism, $\mathrm{Sr}$ has been demonstrated to stimulate bone regeneration and inhibit bone resorption, ${ }^{8-10}$ which has raised great interest in construction of osteoinductive bone biomaterials.

Titanium and its alloy are the most commonly used implant materials for dental and orthopaedic applications due to their good mechanical properties, biocompatibility and corrosion resistance. ${ }^{\mathbf{1 1}, \mathbf{1 2}}$ However, they cannot achieve sufficient

${ }^{a}$ Research Center for Human Tissues and Organs Degeneration, Shenzhen Institutes of Advanced Technology, Chinese Academy of Science, Shenzhen, Guangdong 518055, China.E-mail: gc.wang@siat.ac.cn

${ }^{b}$ School of Materials Science and Engineering, Changzhou University, Changzhou 213164, China. E-mail: zhaoxiaobing00@163.com

$\dagger$ Zhengjiang Xu and Huaifeng Lu are co-first authors, equally contributing to this article. functional integration (osseointegration) with the surrounding bone to establish a firm and long-lasting anchor, as the implant surface lacks osteoinductivity. Therefore, surface activation is required to obtain a satisfactory long-term performance. ${ }^{\mathbf{1 3 , 1 4}}$ Benefiting from the osteogenic function of Sr ions, they have been used by various methods to activate Ti alloy implant surface. ${ }^{15-18}$ The commonest way is to introduce $\mathrm{Sr}$ in a biodegradable material that can be deposited onto the implant surface via a certain of surface techniques. ${ }^{19-21}$ Upon degradation of the material, the $\mathrm{Sr}$ ions release and the resultant biological effects on bone cells can be realized. ${ }^{16}$ However, since the bone implant is supposed to permanently stay in human body, the utilization of a biodegradable coating on its surface could risk the interfacial stability and probably cause implant aseptic loosening upon the coating absorption, if its degradation rate cannot match the new bone formation rate. ${ }^{22}$ Therefore, to better use of the osteogenic benefits of $\mathrm{Sr}$ and avoid the risk of implant loosening caused by the coating degradation, a chemically stable surface coating with an ability to release Sr ions would be preferred.

In this study, we choose biocompatible and chemically stable $\mathrm{TiO}_{2}$ as the main component of the surface coating material, which is supposed to permanently exist during the service time of the implant. Sr ions were incorporated into the $\mathrm{TiO}_{2}$ promote the osseointegration of the implant. To modulate the ion release behavior, the amount of $\mathrm{Sr}$ in the $\mathrm{TiO}_{2}$ was tailored in order to control the $\mathrm{Sr}$ configuration $\left(\mathrm{Sr}-\mathrm{TiO}_{2}\right)$ solid solution and strontium titanate $\left(\mathrm{SrTiO}_{3}\right)$ in the composite 
coating. The release of $\mathrm{Sr}$ is not associated with the degradation of the whole coating material, thus avoiding the risk of compromising the implant stability resulted from by the coating degradation. The ion release behavior, corrosion resistance and bioactivity of the Sr-doped coatings were evaluated and discussed.

\section{Materials and methods}

\subsection{Coating fabrication}

$\mathrm{TiO}_{2}$ and $\mathrm{SrO}$ nanopowders were used as starting materials. $10 \% \mathrm{SrO}^{-} \mathrm{TiO}_{2}, 20 \% \mathrm{SrO}-\mathrm{TiO}_{2}$ and $30 \% \mathrm{SrO}-\mathrm{TiO}_{2}$ composite powders were produced by mixing using planetary ball mill. Coatings were deposited on biomedical grade Ti alloy (Baoji Junhang Metal Material Co., Ltd. Shanxi, China) with a diameter of $15 \mathrm{~mm}$ and $1 \mathrm{~mm}$ thickness by an atmospheric plasma spraying system (9M, Sulzer Metco, USA). Before plasma spraying, the Ti alloy substrates were ultrasonically cleaned in absolute ethanol and sandblasted with brown corundum. For cell culture experiments, the Ti alloy discs without any coatings and with pure $\mathrm{TiO}_{2}$ coating were used as controls. The main parameters used in this study to prepare the $\mathrm{TiO}_{2}, 10 \% \mathrm{SrO}-$ $\mathrm{TiO}_{2}, 20 \% \mathrm{SrO}_{-} \mathrm{TiO}_{2}$ and $30 \% \mathrm{SrO}-\mathrm{TiO}_{2}$ coatings are listed as follows: spraying power was $42 \mathrm{~kW}$, Ar flow rate was $40 \mathrm{~L} \mathrm{~min}^{-1}$, $\mathrm{H}_{2}$ flow rate was $12 \mathrm{~L} \mathrm{~min}^{-1}$, spraying distance was $100 \mathrm{~mm}$ and powder feed rate was $30 \mathrm{~g} \mathrm{~min}^{-1}$.

\subsection{Coating characterization}

2.2.1. X-ray diffraction (XRD) and scanning electron microscopy (SEM). The phase structures of the coatings were conducted by X-ray diffraction (XRD, D/max 2500PC, Rigaku, Japan) with $\mathrm{Cu} \mathrm{K} \alpha$ radiation $(\lambda=1.5418 \AA)$ in the range of 20 $80^{\circ}(2 \theta)$. Scanning electron microscopy (SEM, S-3400, Japan) was used to examine the surface morphology.

2.2.2. Ion release profile. The coatings were immersed in $1 \mathrm{~mL}$ of $\alpha$-minimum essential medium ( $\alpha$-MEM, Hyclone, USA) $(\mathrm{pH}=7.4)$ at $37^{\circ} \mathrm{C}$. The medium was refreshed every $3 \mathrm{~d}$. At each time point $(3,6$ and 9 days), the culture medium was collected for measurement. The ion concentration of $\mathrm{Ti}$ and $\mathrm{Sr}$ in the culture medium was measured by inductively coupled plasma atomic emission spectroscopy (ICP-OES).

2.2.3. In vitro cell-free mineralization. The as-sprayed $\mathrm{TiO}_{2}$ and the SrO doped $\mathrm{TiO}_{2}$ coatings were cleaned in an ultrasonic bath with ethanol and distilled water. Modified simulated body fluid $(2 \times \mathrm{SBF})$ with $\mathrm{Ca}$ and $\mathrm{P}$ ion concentrations double those in the normal simulated body fluid (SBF). The samples were soaked in the $2 \times \mathrm{SBF}$ at $37{ }^{\circ} \mathrm{C}$ for $14 \mathrm{~d}$ without stirring and the solution were refreshed every 7 days. The $2 \times$ SBF solution containing $142.0 \mathrm{mmol} \mathrm{L}^{-1} \mathrm{Na}^{+}, 5.0 \mathrm{mmol} \mathrm{L}^{-1} \mathrm{~K}^{+}, 1.5 \mathrm{mmol} \mathrm{L}^{-1}$ $\mathrm{Mg}^{2+}$, $5.0 \mathrm{mmol} \mathrm{L}{ }^{-1} \mathrm{Ca}^{2+}, 148.5 \mathrm{mmol} \mathrm{L}^{-1} \mathrm{Cl}^{-}, 4.2 \mathrm{mmol} \mathrm{L}^{-1}$ $\mathrm{HCO}_{3}{ }^{-}$and $2.0 \mathrm{mmol} \mathrm{L}^{-1} \mathrm{HPO}_{4}{ }^{2-}$ and $0.5 \mathrm{mmol} \mathrm{L}^{-1} \mathrm{SO}_{4}{ }^{2-}$ was prepared by dissolving the reagents of $\mathrm{NaCl}, \mathrm{NaHCO}_{3}, \mathrm{KCl}$, $\mathrm{K}_{2} \mathrm{HPO}_{4} \cdot \mathrm{H}_{2} \mathrm{O}, \mathrm{MgCl}_{2} \cdot 6 \mathrm{H}_{2} \mathrm{O}, \mathrm{CaCl}_{2}$ and $\mathrm{Na}_{2} \mathrm{SO}_{4}$ into distilled water. The $2 \times \mathrm{SBF}$ solution was buffered at $\mathrm{pH} 7.4$ with Tris and $\mathrm{HCl}^{23}$
2.2.4. Electrochemical measurements. The corrosion resistance of the coatings were measured by the Autolab electrochemical workstation (PGSTAT 302N, METROHM, Swiss) in SBF solution using a three-electrode configuration comprising an $\mathrm{Ag} / \mathrm{AgCl}$ electrode as the reference electrode, a platinum rod as the counter electrode, and the sample as the working electrode. The measurements were performed at room temperature with a scanning rate of $5 \mathrm{mV} \mathrm{s}^{-1}$. The corrosion rate was calculated based on the following equation. ${ }^{24}$

$$
\text { Corrosion rate }=\frac{0.13 \Delta I_{\text {corr }} \Delta E W}{d}
$$

\subsection{Biological test}

2.3.1. Cell culture and seeding. Rats bone marrow mesenchymal stem cells (rBMSCS) was isolated from SD rat bone marrow. SD rats were purchased from Guangdong Medical Laboratory Animal Center (Guangzhou, China). Briefly, bone marrow was rinsed out with complete culture medium consisting of $\alpha$-MEM, $10 \%$ fetal bovine serum (FBS, Gibico, USA) and $1 \%$ antibiotics $\left(100 \mu \mathrm{g} \mathrm{mL}^{-1}\right.$ gentamycin and $100 \mathrm{U} \mathrm{mL}^{-1}$ penicillin). When reaching $80-90 \%$ confluence, cells were digested by $0.25 \%$ trypsin, collected by centrifugation and diluted to the desired density in culture medium. $1 \mathrm{~mL}$ of cell suspension with a density of $2 \times 10^{4}$ cells per $\mathrm{cm}^{2}$ was added onto each samples placed in 24 -well cell culture plates. The medium was refreshed every two days.

2.3.2. Initial cellular attachment. To evaluate the cell attachment, cells were cultured on the samples for $24 \mathrm{~h}$, and then were fixed with $2.5 \%$ glutaraldehyde in $30 \mathrm{~min}$. For SEM, cell were washed with PBS twice and then dehydrated in gradient ethanol solution with final drying by isoamyl acetate. For immunofluorescent staining, the fixed cells were permeabilized with $0.1 \%(\mathrm{v} / \mathrm{v})$ Triton $\mathrm{X}-100$ for $7 \mathrm{~min}$, and the unspecific staining was blocked by incubation in 1\% BSA for $30 \mathrm{~min}$. For focal adhesion staining, the specimens were incubated overnight at $4{ }^{\circ} \mathrm{C}$ with $2 \mu \mathrm{g} \mathrm{mL}{ }^{-1}$ of mouse anti-mouse vinculin primary antibody (Abcam, UK) diluted in 1\% BSA/ PBS solution. After three washes, the sample was then incubated for $1 \mathrm{~h}$ with $2 \mu \mathrm{g} \mathrm{mL} \mathrm{m}^{-1}$ of goat anti-mouse IgG H\&L (Alexa Fluor® 647) (Abcam, UK). The actin cytoskeleton was labeled by Phalloidin-FITC (Sigma, USA) for $45 \mathrm{~min}$, and the cell nucleus was stained by $4^{\prime}, 6$-diamidino-2-phenylindole dihydro-chloride (DAPI, Sigma, USA) for $5 \mathrm{~min}$. The stained cells were observed under the fluorescence microscope (OLYMPUS-BX53, Japan).

2.3.3. Cell proliferation. Cell Viability Kit-8 (CCK-8, Beyotime, China) was used to evaluate the cell proliferation on the coated $\mathrm{Ti}$ alloys. After incubation for 3 and 7 days, culture medium was removed and replaced by $10 \%$ CCK- 8 working solution, followed by $2 \mathrm{~h}$ incubation. The OD values at $450 \mathrm{~nm}$ were read by a multi-well plate reader (Thermo Scientific Multiskan GO, Thermo).

2.3.4. Alkaline phosphates (ALP) activity assay. For alkaline phosphatase (ALP) activity evaluation, after 14 days' incubation, the medium was removed from the cell culture plates and washed with PBS twice, followed by 30 min incubation in $200 \mu \mathrm{L}$ of $1 \%$ Triton X-100 solution containing $100 \mathrm{mM}$ 
Table 1 Primer sequences for polymerase chain reaction

\begin{tabular}{ll}
\hline Gene & Sequences $\left(5^{\prime}-3^{\prime}\right)$ \\
\hline \multirow{2}{*}{ RUNX-2 } & F:ATCCAGCCACCTTCACTTACACC \\
& R:GGGACCATTGGGAACTGATAGG \\
COL-I & F:CTGCCCAGAAGAATATGTATCACC \\
& R:GAAGCAAAGTTCCTCCAAGACC \\
OPN & F:GACGGCCGAGGTGATAGCTT \\
& R:CATGGCTGGTCTTCCCGTGC \\
OCN & F:GCCCTGACTGCATTCTGCCTCT \\
& R:TCACCACCTTACTGCCCTCCTG \\
GAPDH & F:GGCACAGTCAAGGCTGAGAATG \\
& R:ATGGTGGTGAAGACGCCAGTA
\end{tabular}

phenylmethanesulfonyl fluoride (PMSF). Then $50 \mu \mathrm{L}$ of the cell lysates was transferred to a 96-well plate and incubated for $2 \mathrm{~h}$ at $37^{\circ} \mathrm{C}$ with $200 \mu \mathrm{L}$ of $p$-nitrophenyl phosphate substrate solution (pNPP, Sigma, USA). ALP activity was quantified according to the absorbance at a wavelength of $405 \mathrm{~nm}$. The total protein content in each cell lysate was determined using a BCA protein assay kit, to which ALP activity was normalized.

2.3.5. Cell differentiation. RBMSCs were seeded onto the Ti6Al4V, $\mathrm{TiO}_{2}$ and the $\mathrm{SrO}$ doped $\mathrm{TiO}_{2}$ coatings at density of $2 \times$ $10^{4}$ cells per $\mathrm{cm}^{2}$ and cultured for 7 and 14 days. The total RNA isolation and qPCR were performed strictly following the instruction from the assay kit provider. The forward and reverse primers of the selected genes are listed in Table 1. Detailed information about the experimental procedure can be found in our previous work. ${ }^{25}$

\subsection{Statistical analysis}

For statistical analysis, SPSS 17.0 program was used and the data were expressed as mean $\pm \mathrm{SD}$. Levene's test was performed to determine the homogeneity of variance for all the data. Tukey HSD post hoc tests were used for the data with homogeneous variance. Tamhane's $T 2$ post hoc was employed in the case that the tested group did not have a homogeneous variance. A $p$ value of less than 0.05 was considered significant.

\section{Results}

\subsection{XRD analysis}

Fig. 1 shows the XRD patterns of the $\mathrm{TiO}_{2}, 10 \% \mathrm{SrO}^{-\mathrm{TiO}_{2}}, 20 \%$ SrO- $\mathrm{TiO}_{2}$ and $30 \% \mathrm{SrO}-\mathrm{TiO}_{2}$ coatings on Ti alloy substrates. In the diffraction pattern of the $\mathrm{TiO}_{2}$ coating, peaks at $2 \theta$ values of $27.4^{\circ}, 36.1^{\circ}, 41.2^{\circ}, 54.3^{\circ}$ and $62.7^{\circ}$ are assigned to (110), (101), (111), (211) and (002) crystalline planes of rutile $\mathrm{TiO}_{2}$. For the doped $\mathrm{TiO}_{2}$ coatings, the characteristic peaks of $\mathrm{SrTiO}_{3}$ at $32.4^{\circ}$ and $39.9^{\circ}$ were found, and their intensity increases as the amount of $\mathrm{SrO}$ in the coating increases. The relative ratio of $\mathrm{SrTiO}_{3} / \mathrm{TiO}_{2}$ in the $10 \% \mathrm{SrO}-\mathrm{TiO}_{2}, 20 \% \mathrm{SrO}-\mathrm{TiO}_{2}, 30 \% \mathrm{SrO}-\mathrm{TiO}_{2}$ coatings, calculated based on the relative peak intensity was $0.067,0.246,0.915$, respectively. It is noted that with increase in the $\mathrm{Sr}$ amount in the coating, the intensity of diffraction peaks of rutile weakened, whereas those of anatase $\left(25.3^{\circ}\right)$ strengthened, indicating more anatase $\mathrm{TiO}_{2}$ appeared in the $\mathrm{SrO}$ doped $\mathrm{TiO}_{2}$ coatings.

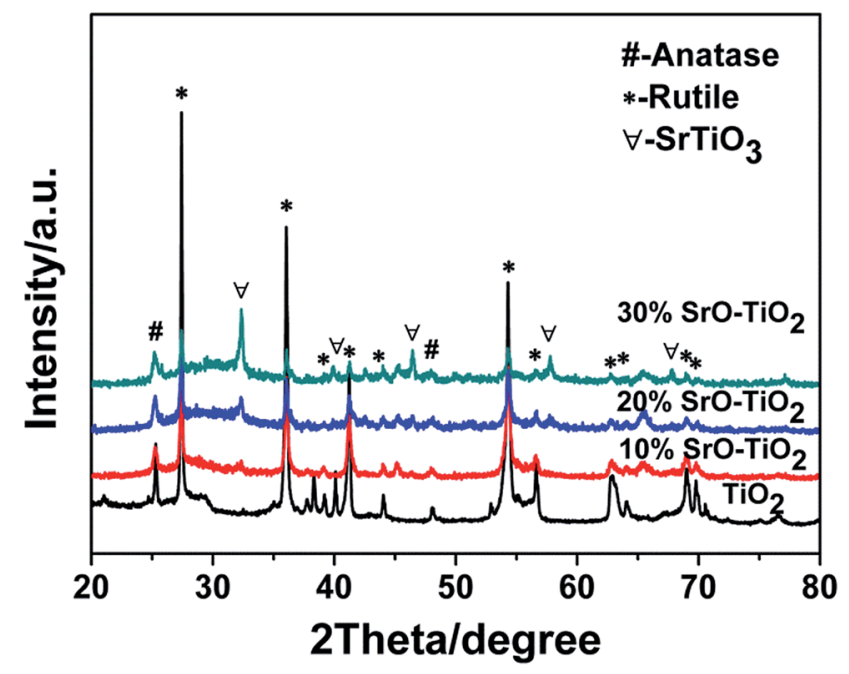

Fig. 1 XRD patterns of the $\mathrm{TiO}_{2}$ and $\mathrm{SrO}-\mathrm{TiO}_{2}$ coatings.

\subsection{Morphology and structural characterization}

The SEM images of the surface morphology of the $\mathrm{TiO}_{2}$-based coatings are showed in Fig. 2. All the coatings show a typical morphology of a plasma sprayed coating, having a rough surface with a surface roughness of 4-6 $\mu \mathrm{m}$ (Fig. 2A-D). No significant difference was found among the $\mathrm{TiO}_{2}, 10 \% \mathrm{SrO}-$ $\mathrm{TiO}_{2}, 20 \% \mathrm{SrO}-\mathrm{TiO}_{2}$ and $30 \% \mathrm{SrO}-\mathrm{TiO}_{2}$ coatings.

\subsection{Electrochemical measurements}

Fig. 3 displays the potentiodynamic polarization curves of the $\mathrm{TiO}_{2}, 10 \% \mathrm{SrO}-\mathrm{TiO}_{2}, 20 \% \mathrm{SrO}_{-}-\mathrm{TiO}_{2}$ and $30 \% \mathrm{SrO}-\mathrm{TiO}_{2}$ coatings in SBF solution. The corrosion potential $\left(E_{\text {corr }}\right)$, corrosion current density $\left(I_{\text {corr }}\right)$ and corrosion rate of the films calculated based on the polarization curves are listed in Table 2. The $20 \% \mathrm{SrO}_{-} \mathrm{TiO}_{2}$ coating $(-573.7 \mathrm{mV})$ and the $\mathrm{TiO}_{2}$ coating $(-570.34 \mathrm{mV})$ have a comparable $E_{\text {corr }}$, which is less negative than those of the $10 \%$ SrO- $\mathrm{TiO}_{2}(-599.7 \mathrm{mV})$ coating. The $I_{\text {corr }}$ of the $20 \% \mathrm{SrO}-\mathrm{TiO}_{2}$ coating $\left(1.92 \mu \mathrm{A} \mathrm{cm}^{-2}\right)$ is slightly lower than that of the $10 \% \mathrm{SrO}-$ $\mathrm{TiO}_{2}$ coating $\left(2.06 \mu \mathrm{A} \mathrm{cm}{ }^{-2}\right)$, but obviously higher than that of the $\mathrm{TiO}_{2}$ coating $\left(2.70 \mu \mathrm{A} \mathrm{cm}{ }^{-2}\right)$. The corrosion rate calculated based on the $I_{\text {corr }}$ has the same tendency. Compared to other coatings, the $30 \%$ SrO- $\mathrm{TiO}_{2}$ coating has the most negative $E_{\text {corr }}$ $(-1048.5 \mathrm{mV})$ and the highest $I_{\text {corr }}\left(7.90 \mu \mathrm{A} \mathrm{cm} \mathrm{cm}^{-2}\right) /$ corrosion rate. These results suggest that the $20 \% \mathrm{SrO}-\mathrm{TiO}_{2}$ coating has the best corrosion resistance while the $30 \% \mathrm{SrO}-\mathrm{TiO}_{2}$ coating has the worst. It was reported that a lower point of zero charge (PZC) of materials exhibits a higher pitting potential and better corrosion resistance. ${ }^{26-29}$ It was found that the $\mathrm{PZC}$ of $\mathrm{SrTiO}_{3}$ is around 8.59.5, higher than that of $\mathrm{TiO}_{2}(5-7),{ }^{27}$ which could be one of the possible reasons for the deteriorated corrosion resistance of the $30 \% \mathrm{SrO}-\mathrm{TiO}_{2}$ coating. In addition, the corrosion resistance of the coating is also strongly influenced by the structural defects, such as microcracks and pores etc. Future work will be carried to investigate into the influence of the amount of $\mathrm{Sr}$ on the microstructures of the $\mathrm{SrO}-\mathrm{TiO}_{2}$ coatings. 

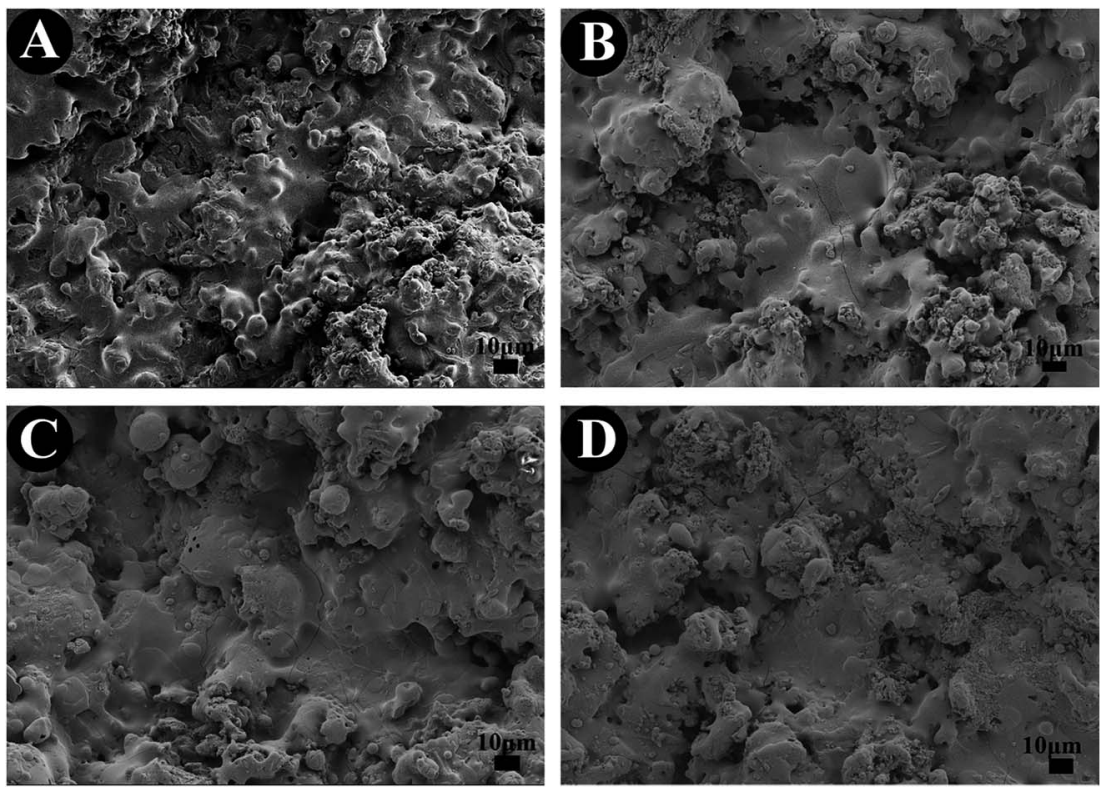

Fig. $2 \mathrm{SEM}$ images of the $\mathrm{TiO}_{2}$ (A), 10\% $\mathrm{SrO}-\mathrm{TiO}_{2}$ (B), 20\% $\mathrm{SrO}-\mathrm{TiO}_{2}$ (C) and $30 \% \mathrm{SrO}-\mathrm{TiO}_{2}$ (D) coatings.

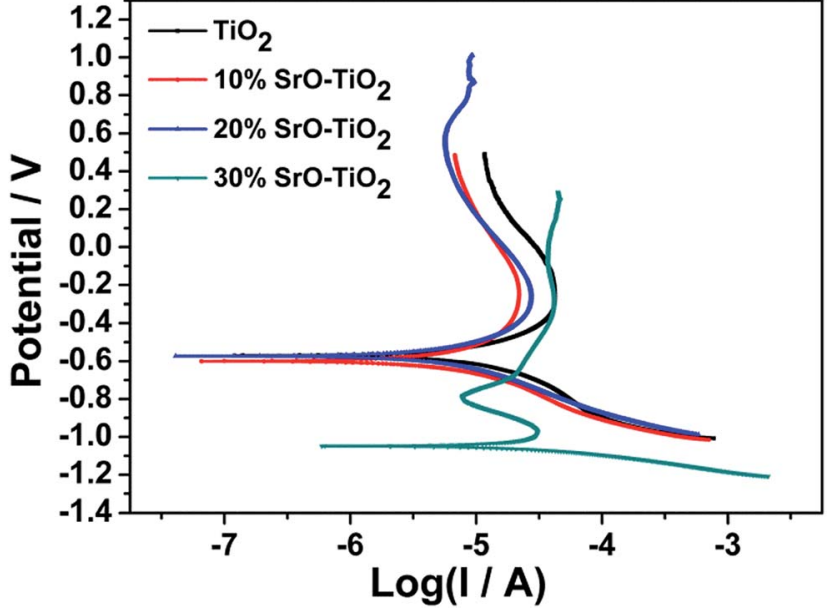

Fig. 3 Potentiodynamic polarization curves of $\mathrm{TiO}_{2}, 10 \% \mathrm{SrO}-\mathrm{TiO}_{2}$ $20 \% \mathrm{SrO}-\mathrm{TiO}_{2}, 30 \% \mathrm{SrO}-\mathrm{TiO}_{2}$ coatings.

Table $2 E_{\text {corr }} I_{\text {corr }}$ and corrosion rate of the coatings

\begin{tabular}{llll}
\hline Sample & $E_{\text {corr }}(\mathrm{mV})$ & $I_{\text {corr }}\left(\mu \mathrm{A} \mathrm{cm}{ }^{-2}\right)$ & $\begin{array}{l}\text { Corrosion rate } \\
(\mathrm{mm} \text { per year })\end{array}$ \\
\hline $\mathrm{TiO}_{2}$ & -570.34 & 2.6971 & 0.09363 \\
$10 \% \mathrm{SrO}^{-\mathrm{TiO}_{2}}$ & -599.7 & 2.0559 & 0.071371 \\
$20 \% \mathrm{SrO}-\mathrm{TiO}_{2}$ & -573.7 & 1.9233 & 0.066768 \\
$30 \% \mathrm{SrO}-\mathrm{TiO}_{2}$ & -1048.5 & 7.8986 & 0.2742
\end{tabular}

\subsection{In vitro mineralization}

Fig. 4 represents the surface morphologies of the $\mathrm{TiO}_{2}, 10 \% \mathrm{SrO}-$ $\mathrm{TiO}_{2}, 20 \% \mathrm{SrO}_{-}-\mathrm{TiO}_{2}$ and $30 \% \mathrm{SrO}^{-} \mathrm{TiO}_{2}$ coatings after immersion in $2 \times$ SBF for 14 days. A large amount of granular precipitation is observed on the $\mathrm{TiO}_{2}, 10 \%$ and $20 \% \mathrm{SrO}-\mathrm{TiO}_{2}$ coatings, while few observed on the $30 \% \mathrm{SrO}^{-} \mathrm{TiO}_{2}$ coating. Under higher magnifications, it can be seen that the precipitated granules consist of nanosized plate-like crystals. EDS results prove that the precipitation is mainly composed of $\mathrm{Ca}$ and $\mathrm{P}$ (top left insets). On the $\mathrm{TiO}_{2}$ coating, the precipitation almost covers the whole surface, showing the best ability to induce in vitro mineralization. Among the $\mathrm{SrO}$ doped $\mathrm{TiO}_{2}$ coatings, the amount of precipitation formed on the $10 \% \mathrm{SrO}_{-} \mathrm{TiO}_{2}$ coating seems the largest, followed by the $20 \% \mathrm{SrO}^{-\mathrm{TiO}_{2}}$ coating. Fig. 5 shows XRD results of the coatings soaked in $2 \times \mathrm{SBF}$ for 14 days. The characteristic peaks at $25.8^{\circ}$ and $31.6^{\circ}$ corresponding to hydroxyapatite were observed in the XRD patterns, indicating that the newly formed precipitate was hydroxyapatite. In addition, the relative intensity ratio of HAp to $\mathrm{TiO}_{2}$ is also found to decrease inversely with the $\mathrm{Sr}$ amount, consistent with what we observed from the SEM images (Fig. 4). These results suggest that the addition of SrO compromises the ability of the $\mathrm{TiO}_{2}$ coating to induce apatite formation. Further work will be carried to illustrate the underlying mechanisms.

\subsection{Ion release profile in culture medium}

The $\mathrm{Sr}$ ion release behavior of the $\mathrm{TiO}_{2}, 10 \% \mathrm{SrO}^{-\mathrm{TiO}_{2}}, 20 \%$ $\mathrm{SrO}-\mathrm{TiO}_{2}$ and $30 \% \mathrm{SrO}^{-\mathrm{TiO}_{2}}$ coatings were evaluated over 9 days and the release profile is shown in Fig. 6 . It can be seen that $\mathrm{Sr}$ is releasable in all the doped $\mathrm{TiO}_{2}$ coatings, and its concentration in the immersion medium increases as the immersion time extended from 3 days to 9 days (Fig. 6A). As shown in Fig. 6B, the Sr concentration at each times for the SrO doped $\mathrm{TiO}_{2}$ coating is linearly related to the relative amount of $\mathrm{SrO}$ in the starting composite powders.

\subsection{Cell adhesion and morphology}

Fig. 7A shows fluorescence microscope images of the cell cultured on the Ti6Al4V, $\mathrm{TiO}_{2}, 10 \% \mathrm{SrO}-\mathrm{TiO}_{2}, 20 \% \mathrm{SrO}-\mathrm{TiO}_{2}$ 

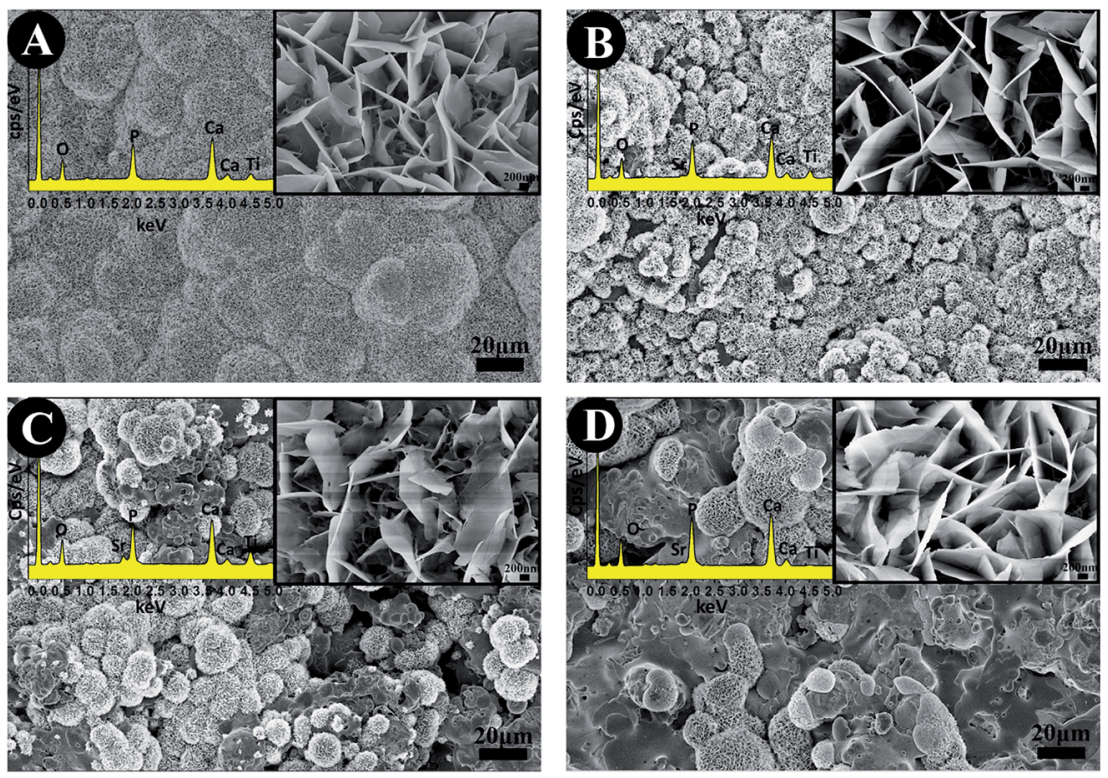

Fig. 4 The surface morphology of the $\mathrm{TiO}_{2}$ (A), 10\% $\mathrm{SrO}-\mathrm{TiO}_{2}$ (B), 20\% SrO- $\mathrm{TiO}_{2}$ (C), 30\% $\mathrm{SrO}-\mathrm{TiO}_{2}$ (D) coatings after immersion in $2 \times \mathrm{SBF}$ for 14 days.

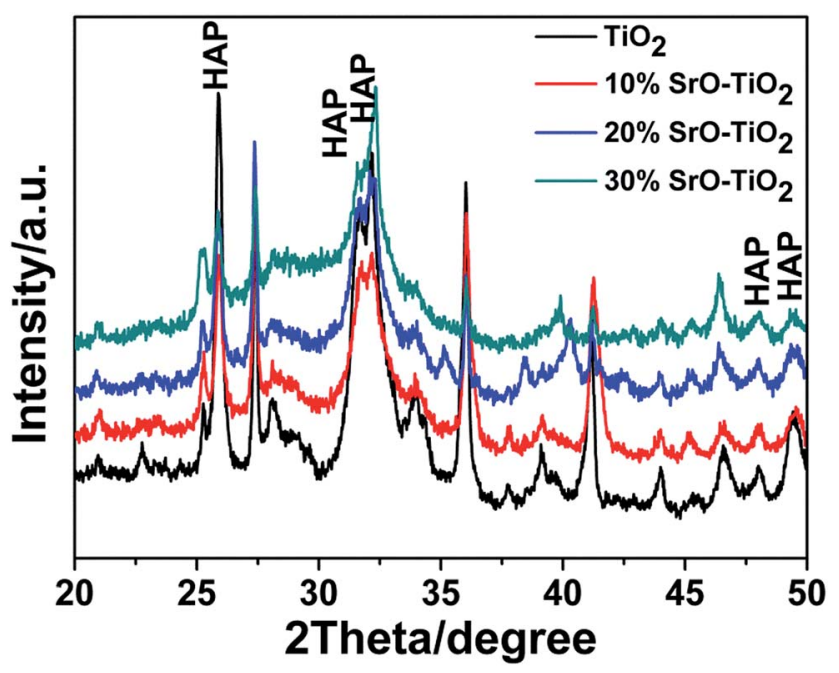

Fig. 5 XRD patterns of the $\mathrm{TiO}_{2}$ coating and the $\mathrm{SrO}-\mathrm{TiO}_{2}$ coatings soaked in $2 \times$ SBF for 14 days.

and $30 \% \mathrm{SrO}_{-} \mathrm{TiO}_{2}$ coatings for $24 \mathrm{~h}$. Cells on all the coatings get flattened and well attach to their underlying substrates. Among these coatings, the cells cultured on the $10 \% \mathrm{SrO}^{-\mathrm{TiO}_{2}}$ coating and the $20 \% \mathrm{SrO}-\mathrm{TiO}_{2}$ coating, especially the latter one, exhibit distinct and well-defined stress fibers and cytoskeleton.

Fig. 7B shows the SEM images of the cells cultured on the samples for $24 \mathrm{~h}$. Most of the cells on the $\mathrm{Ti}, \mathrm{TiO}_{2}, 10 \% \mathrm{SrO}-$ $\mathrm{TiO}_{2}$ and $20 \% \mathrm{SrO}-\mathrm{TiO}_{2}$ coatings exhibit a flattened polygonal shapes, while those on the $30 \% \mathrm{SrO}^{-\mathrm{TiO}_{2}}$ coatings are less flattened.

\subsection{Cell viability and proliferation}

Cell proliferation results are shown in Fig. 8A. At day 3, cells cultured on the $20 \% \quad \mathrm{SrO}-\mathrm{TiO}_{2}$ coatings show higher proliferation rates than those cultured on the $\mathrm{TiO}_{2}, 10 \% \mathrm{SrO}-$ $\mathrm{TiO}_{2}$ and $30 \% \mathrm{SrO}-\mathrm{TiO}_{2}$ coating. After culturing for 7 days, the proliferation rate of the cells on the $20 \% \mathrm{SrO}^{-\mathrm{TiO}_{2}}$ coating is still the highest, followed by that on the $10 \% \mathrm{SrO}^{-\mathrm{TiO}_{2}}$ coating, while the cells on the $30 \% \mathrm{SrO}-\mathrm{TiO}_{2}$ coating exhibit the lowest proliferation rate. The average proliferation rate for the cells on the $\mathrm{TiO}_{2}$ coating is higher than that on the Ti6Al4V, but without significant statistic difference. These results indicate that $\mathrm{Sr}$ doping has great effects on the cell proliferation on the coatings and the $20 \% \mathrm{SrO}-\mathrm{TiO}_{2}$ coating has the best positive effect.

\subsection{Alkaline phosphatase (ALP) activity}

Fig. 8B shows the ALP activity of the cells cultured on the

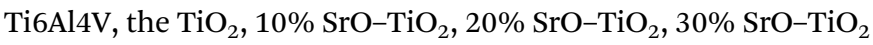
coatings at day 14 . It can be seen that the ALP activity of the cells cultured on the $10 \% \mathrm{SrO}-\mathrm{TiO}_{2}$ coating and the $20 \% \mathrm{SrO}-\mathrm{TiO}_{2}$ coating is comparable, which is significantly higher than those for the cells on the Ti6Al4V and the $\mathrm{TiO}_{2}$ coating. The ALP activity of the cells on the $30 \% \mathrm{SrO}-\mathrm{TiO}_{2}$ coating is lowest.

\section{9. mRNA expression of the osteogenic-related genes}

Fig. 9 displays the expression of the osteogenic-related genes by the cells cultured on the $\mathrm{Ti6Al} 4 \mathrm{~V}$, the $\mathrm{TiO}_{2}$ coating, and the SrOdoped $\mathrm{TiO}_{2}$ coatings. Among these genes, RUNX-2 and COL-I are early markers, while OCN and OPN are later markers for osteogenic differentiation. As shown in Fig. 9, after 7 days, the COL-I expression levels by the cells cultured on the $\mathrm{TiO}_{2}$ coating, the $10 \% \mathrm{SrO}_{-} \mathrm{TiO}_{2}$ coating and the $20 \% \mathrm{SrO}-\mathrm{TiO}_{2}$ coating are significantly higher than those on the Ti6Al4V and the $30 \% \mathrm{SrO}_{-} \mathrm{TiO}_{2}$ coating. At day 14, the COL-I expression level on the $20 \% \mathrm{SrO}-\mathrm{TiO}_{2}$ coating become the highest, which nearly doubles those for the other coatings. For OCN, no difference is found for all the samples at day 7. However, the cells cultured 

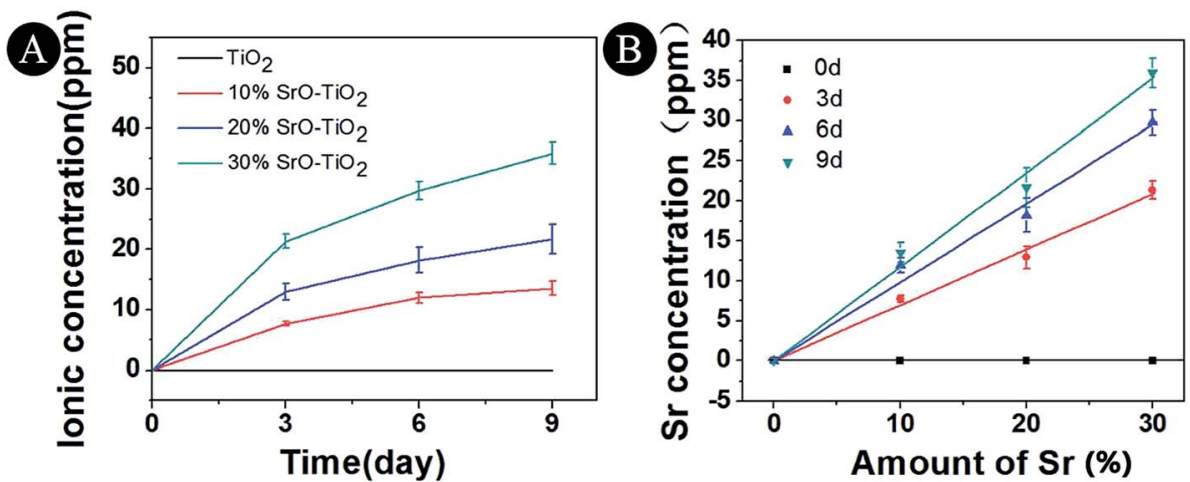

Fig. 6 Concentrations of $\mathrm{Sr}$ ions released from $\mathrm{TiO}_{2}, 10 \% \mathrm{SrO}-\mathrm{TiO}_{2}, 20 \% \mathrm{SrO}-\mathrm{TiO}_{2}, 30 \% \mathrm{SrO}-\mathrm{TiO}_{2}$ coatings after immersion in culture medium for 3,6 and 9 days

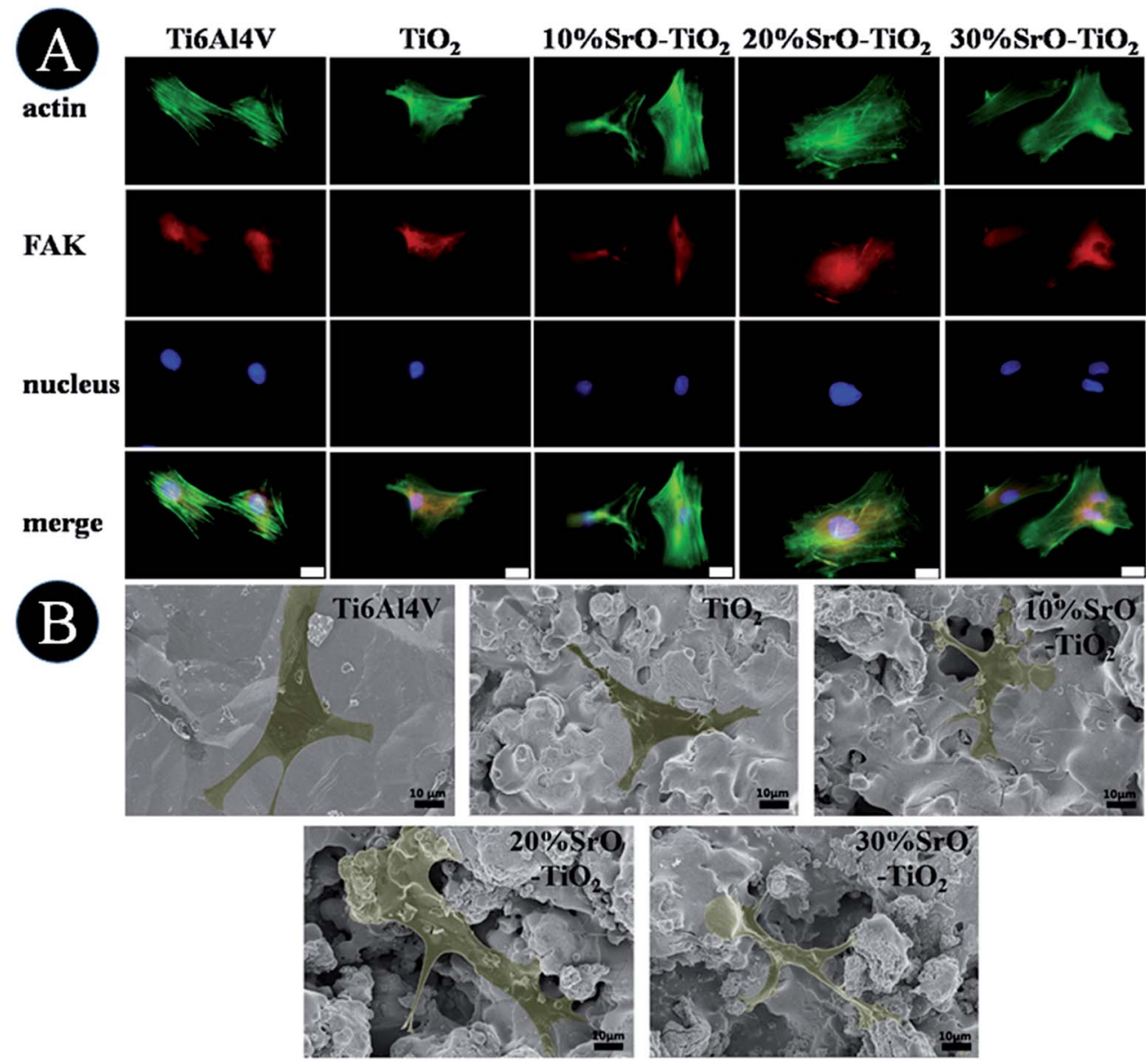

Fig. 7 Observation of cell initial attachment on the coatings, fluorescence microscope images (A) and SEM (B) of cells cultured on Ti6Al4V, TiO 2 , $10 \% \mathrm{SrO}-\mathrm{TiO}_{2}, 20 \% \mathrm{SrO}-\mathrm{TiO}_{2}, 30 \% \mathrm{SrO}-\mathrm{TiO}_{2}$ for $24 \mathrm{~h}$. Scale bar, $20 \mu \mathrm{m}$.

on the $20 \% \mathrm{SrO}^{-\mathrm{TiO}_{2}}$ coating display the highest OCN expression level at day 14 and no significant difference can be seen between the $10 \%$ SrO- $\mathrm{TiO}_{2}$ coating and the $30 \% \quad \mathrm{SrO}-\mathrm{TiO}_{2}$ coating. For OPN, its levels expressed by the cells on the $10 \%$ SrO- $-\mathrm{TiO}_{2}$ coating and the $20 \%$ SrO- $\mathrm{TiO}_{2}$ coating are comparable and significantly higher than those for the other coatings at day 7. After culturing for 14 days, no significant difference can be found anymore between the $10 \% \mathrm{SrO}^{-\mathrm{TiO}_{2}}$ coating and $20 \% \mathrm{SrO}-\mathrm{TiO}_{2}$ coating, but their expression levels are higher than the control groups. For RUNX-2, at both day 7 and 14, its expression levels by the cells cultured on the $10 \% \mathrm{SrO}_{-} \mathrm{TiO}_{2}$ coating and the $20 \% \mathrm{SrO}^{-} \mathrm{TiO}_{2}$ coating are comparable and higher than those by the cells on the control groups. Again, the cells cultured on the $30 \% \mathrm{SrO}^{-\mathrm{TiO}_{2}}$ coating show the lowest 

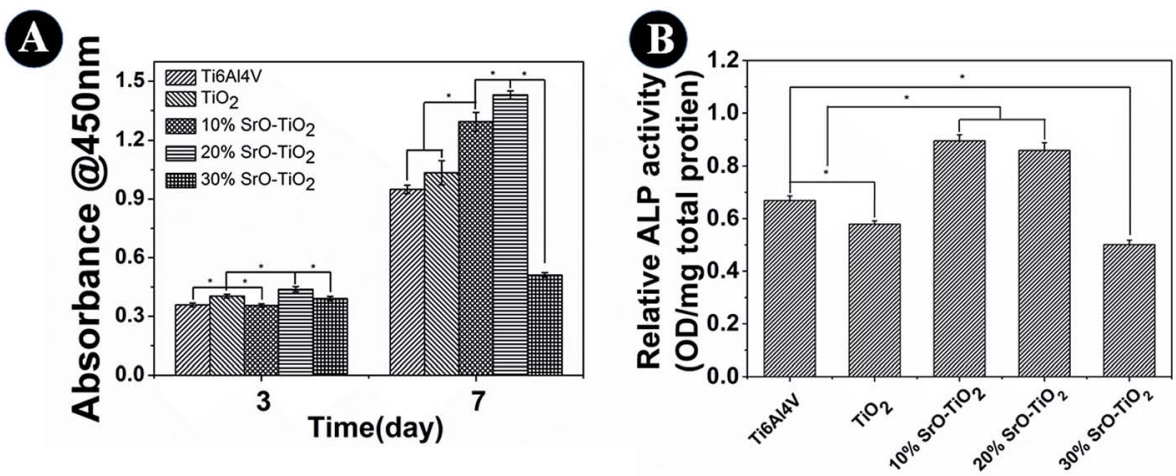

Fig. 8 The proliferation and ALP activity and of rBMSCs cultured on the Ti6Al4V, $\mathrm{TiO}_{2}, 10 \% \mathrm{SrO}-\mathrm{TiO}_{2}, 20 \% \mathrm{SrO}_{-} \mathrm{TiO}_{2}, 30 \% \mathrm{SrO}-\mathrm{TiO} 2 \mathrm{coatings}$ at day 14.
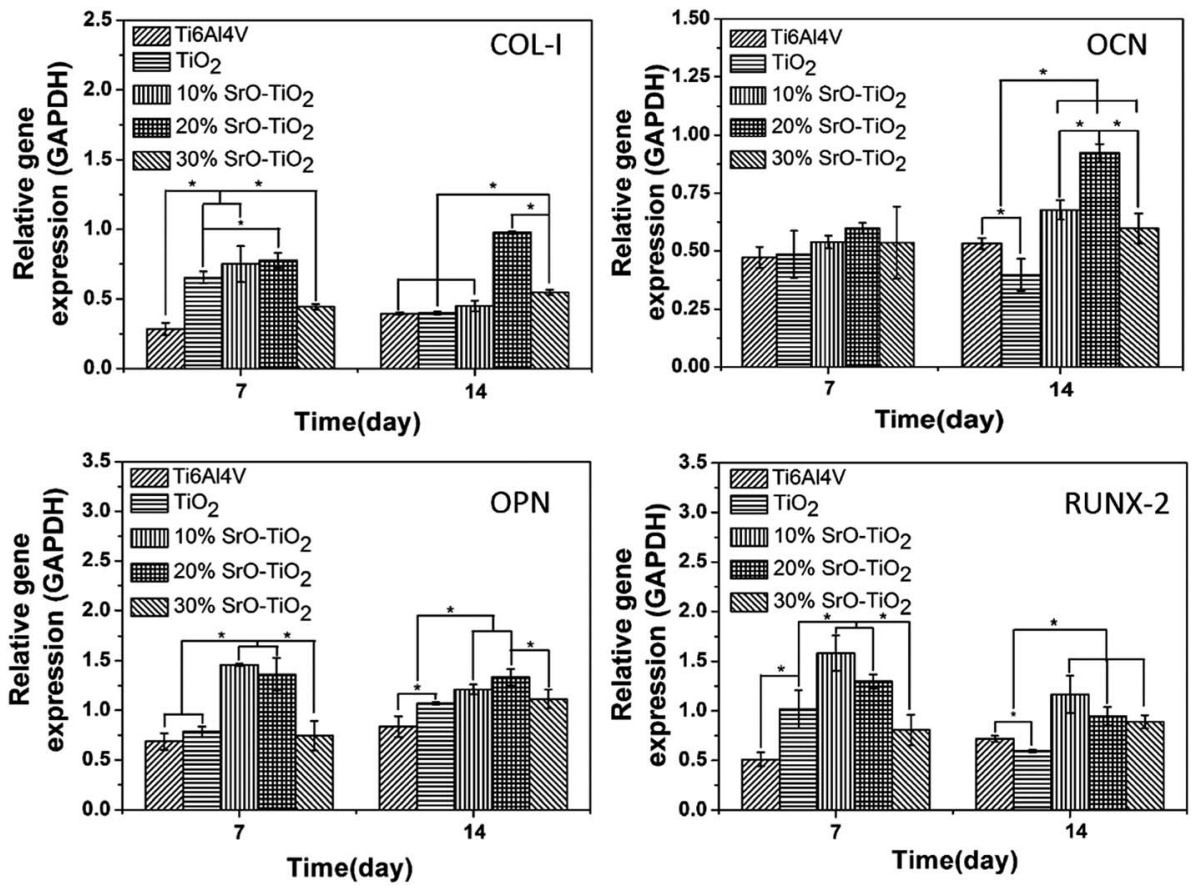

Fig. 9 Quantitative PCR analysis of the cells cultured on $\mathrm{TiO}_{2}, 10 \% \mathrm{SrO}-\mathrm{TiO}_{2}, 20 \% \mathrm{SrO}-\mathrm{TiO}_{2}, 30 \% \mathrm{SrO}-\mathrm{TiO} \mathrm{O}_{2}$ coatings for 7 and 14 days, housekeeping gene GAPDH was used as an internal control. *Statistically significant difference among different samples $(p<0.05)$.

expression level. In general, it can be concluded from these results that the $20 \% \mathrm{SrO}-\mathrm{TiO}_{2}$ coating are superior to the others in promoting osteogenic differentiation, while the $30 \% \mathrm{SrO}-$ $\mathrm{TiO}_{2}$ coating showed obviously less osteogenic activity compared to the other doped coatings.

\section{Discussion}

In this study, we developed $\mathrm{SrO}-\mathrm{TiO}_{2}$ coatings to enhance the osseointegration of the metallic orthopaedic implant. Compared to the commonly used biodegradable Sr-containing biomedical coating, ${ }^{30-34}$ the combination of bioactive $\mathrm{Sr}$ and non-degradable $\mathrm{TiO}_{2}$ in this study endowed the coating with an ability to release bioactive Sr (Fig. 6) and thus obviously improving the osteogenic activity (Fig. 9). It should be noted that the release of $\mathrm{Sr}$ is not combined with the release of $\mathrm{Ti}$, indicating that the release of $\mathrm{Sr}$ in the developed coating system is selective, which will benefit the long-term stability of the implant.

In the SrO-doped $\mathrm{TiO}_{2}$ coatings, the $\mathrm{Sr}$ exists in two different configurations: $\mathrm{Sr}$ intercalated in $\mathrm{TiO}_{2}$ lattice and $\mathrm{SrTiO}_{3}$. In the $10 \% \mathrm{SrO}_{-} \mathrm{TiO}_{2}$ coating, the amount of $\mathrm{SrTiO}_{3}$ calculated from XRD patterns is around $6.31 \mathrm{wt} \%$. The atomic ratio of the $\mathrm{Sr}$ in the $\mathrm{SrTiO}_{3}$ relative to the total amount of $\mathrm{Ti}$ in this coating is 0.017 , much less than the theoretic value of 0.052 , suggesting that there must be some part of $\mathrm{Sr}(0.035)$ existing in other configurations. Based on the solid solution and doping theory, the most possible configuration of $\mathrm{Sr}$ is as interstitial atoms of the $\mathrm{TiO}_{2}$ lattice in $\mathrm{SrO}-\mathrm{TiO}_{2}$ solid solution (Fig. 1). When the SrO amount increases to $20 \%$, the percent of $\mathrm{SrTiO}_{3}$ is around 
$19.7 \mathrm{wt} \%$, leading to a $\mathrm{Sr} / \mathrm{Ti}$ of 0.061 , which is nearly half of the theoretic value $(0.115)$. Therefore, there are also a large part of Sr existing as an interstitial solute in the $\mathrm{SrO}^{-} \mathrm{TiO}_{2}$ solid solution. ${ }^{35,36}$ However, in the $30 \% \mathrm{SrO}^{-\mathrm{TiO}_{2}}$ coating, the ratio of $\mathrm{Sr}$ in $\mathrm{SrTiO}_{3}$ relative to the total Ti in the coating (0.193) is very close to the theoretic value $(0.198)$, therefore, it can been concluded that $\mathrm{Sr}$ in this coating exists only in the form of $\mathrm{SrTiO}_{3}$. Therefore, the ion release of $\mathrm{Sr}$ from the SrO-doped $\mathrm{TiO}_{2}$ coating is contributed by two different $\mathrm{Sr}$ configurations. For the $10 \% \mathrm{SrO}-\mathrm{TiO}_{2}$ coating and the $20 \% \mathrm{SrO}-\mathrm{TiO}_{2}$ coating, the released $\mathrm{Sr}$ is from both $\mathrm{SrTiO}_{3}$ and the $\mathrm{Ti}_{y} \mathrm{Sr}_{2-2 y} \mathrm{O}_{2}$ solid solution, whereas that for the $30 \% \mathrm{SrO}-\mathrm{TiO}_{2}$ coating is solely from $\mathrm{SrTiO}_{3}$. As shown in Fig. 6, the linear release behavior was achieved for all the coatings by the two Sr configurations, suggesting that the $\mathrm{Sr}$ release could be precisely controlled by adjusting the amount of $\mathrm{Sr}$ and the Sr configurations in the coating. However, it should be noted that there are numerous nanosized crystals precipitated on the surface of the $30 \% \mathrm{SrO}-$ $\mathrm{TiO}_{2}$ coating after incubation with cells for $24 \mathrm{~h}$, as shown in Fig. 10A. Based on the EDS results, the Sr/Ti ratio of the newly formed crystals is around 0.45 , nearly doubles the theoretical value of 0.19 , implying that the newly formed crystals is a Sr-rich compound. Based on this, it can be deduced that the Sr released from the $30 \% \mathrm{SrO}^{-} \mathrm{TiO}_{2}$ coating possibly led to an increased supersaturation degree with respective to a certain of $\mathrm{Sr}$ containing compound, which "recycles" the released Sr ions, and ultimately decreased the ion concentration in their extracts. ${ }^{37}$ Therefore, the linear release behavior for the $30 \%$ $\mathrm{SrO}-\mathrm{TiO}_{2}$ with respective to the SrO amount is also contributed by the newly formed layer of the crystals.
The $\mathrm{TiO}_{2}$ powders we used in this study are composed of $85 \%$ anatase and $15 \%$ rutile $\mathrm{TiO}_{2}$. However, it can be seen that the relative amount of the anatase $\mathrm{TiO}_{2}$ was significantly reduced after plasma spaying, indicating that plasma spraying promotes the phase transformation from anatase to rutile (Fig. 10B). With the increase in the amount of Sr in the coating, the relative amount of the anatase $\mathrm{TiO}_{2}$ increases, applying that the $\mathrm{Sr}$ incorporation can suppress the anatase to rutile transformation. It is well-known that rutile and anatase are two most common phases for $\mathrm{TiO}_{2} \cdot{ }^{38} \mathrm{~V}$. Sollazzo reported that anatase $\mathrm{TiO}_{2}$ has better bioactivity compared to the rutile phase. ${ }^{39}$ Although no direct evidence is obtained in this study to proof the contribution of the anatase $\mathrm{TiO}_{2}$ on the bioactivity, the rutile to anatase transformation caused by Sr doping still could be a merit of our coating design, which might provide some guidance for further biomedical coating design based on the $\mathrm{TiO}_{2}$ material. Based on the biological results, we found that the $20 \% \mathrm{SrO}^{-} \mathrm{TiO}_{2}$ coating not only promoted the proliferation of rBMSCs (Fig. 8A), but also enhanced their osteogenic differentiation, as indicated in the ALP activity (Fig. 8B) and gene expression levels (Fig. 9), which is closely related to the $\mathrm{Sr}$ ions released from the coating. To illustrate the dominant effects of the $\mathrm{Sr}$ ion on the enhancement of the osteogenic activity, we used the extract of the samples to culture the rBMSCs to evaluate the biological effects of the dissolution products. The expression levels of bone-related genes (OPN, RUNX-2, COL-I and OCN) by the cells cultured for 7 days in the extracts were presented in Fig. 10C. It can be seen that the cells cultured by the extract of the $20 \% \mathrm{SrO}-\mathrm{TiO}_{2}$ coating express the highest levels of these genes, whereas those cultured in the extract of
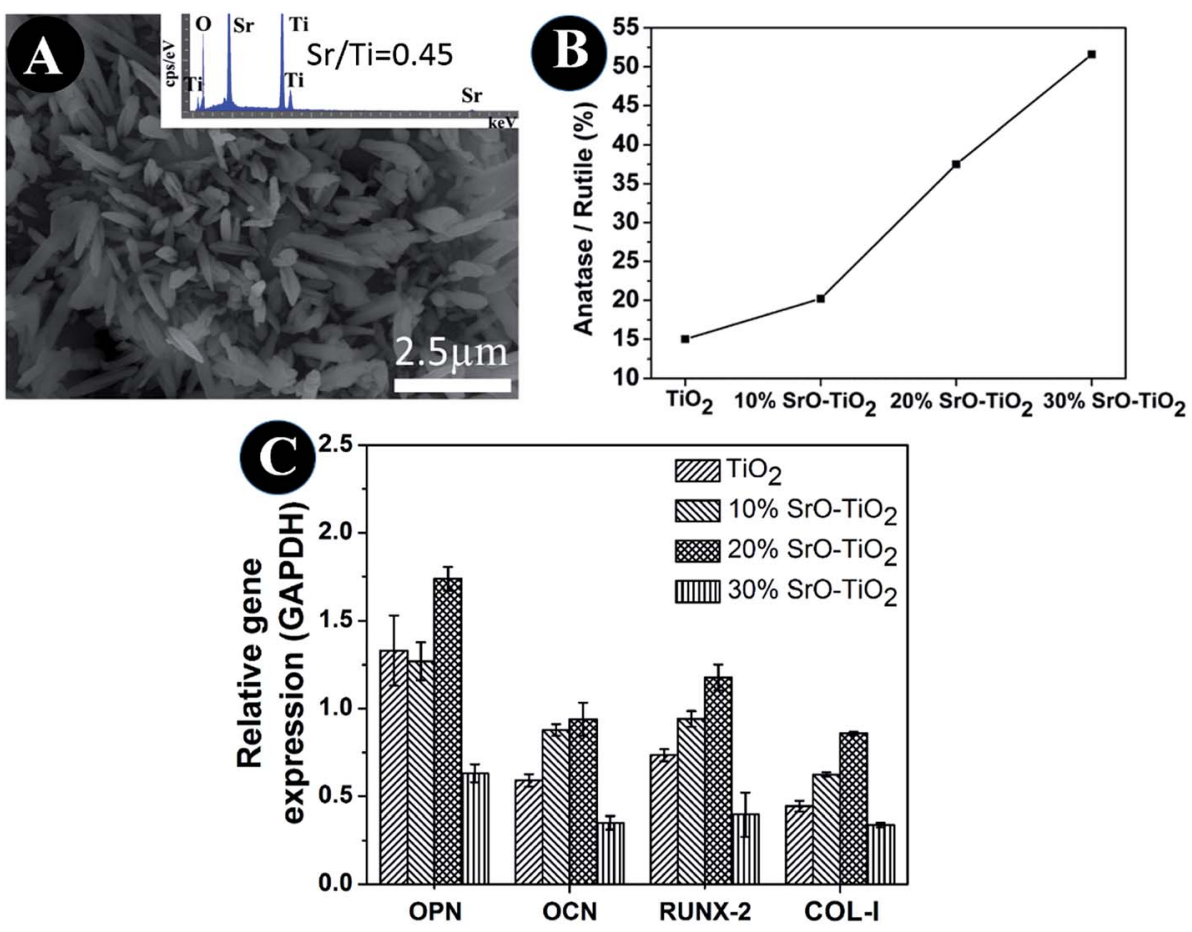

Fig. 10 SEM and EDS of crystals precipitated on its surface after incubation with cells for $24 \mathrm{~h}(\mathrm{~A})$, the ratio of anatase and rutile phase in the composite coatings (B), quantitative PCR analysis of the cells cultured on $\mathrm{TiO}_{2}, 10 \% \mathrm{SrO}-\mathrm{TiO}_{2}, 20 \% \mathrm{SrO}_{-} \mathrm{TiO}_{2}, 30 \% \mathrm{SrO}_{-} \mathrm{TiO} \mathrm{Coatings}_{2}$ dissolution products (C). 
the $30 \% \quad \mathrm{SrO}_{-} \mathrm{TiO}_{2}$ coating express the lowest levels. The consistency of the gene expression results for the cells directly cultured on the coating surface and incubated with the coating extracts further validates the importance of $\mathrm{Sr}$ ions for the osteogenic activity. Similar to the biological drugs, the effects of the bioactive ions are also does-dependent. ${ }^{\mathbf{1 0 , 4 0 , 4 1}}$ Therefore, based on the biological results, we may conclude that the $\mathrm{Sr}$ ions released from the $20 \% \mathrm{SrO}-\mathrm{TiO}_{2}$ coating is the optimal and the $\mathrm{Sr}$ ions from the $30 \% \mathrm{SrO}-\mathrm{TiO}_{2}$ coating are possibly overdosed.

\section{Conclusion}

In summary, non-degradable bioactive coating was designed based a $\mathrm{SrO}-\mathrm{TiO}_{2}$ system in this work, which is able to selectively release $\mathrm{Sr}$ ions. It was proven that the release of $\mathrm{Sr}$ ions is dependent on the Sr configurations in the coating, which has great influence on the osteogenic activity of the bone cells. $\mathrm{Sr}$ mainly exists as interstitial atoms in a solid solution of $\mathrm{Ti}_{y^{-}}$ $\mathrm{Sr}_{2-2 y} \mathrm{O}_{2}$ when its amount is less than $10 \mathrm{wt} \%$, and only $\mathrm{SrTiO}_{3}$ configuration appears when the $\mathrm{Sr}$ amount is higher than $30 \%$. Both configurations present in the coatings with a Sr amount lying in between. We found that the addition of Sr compromises the in vitro mineralization ability of the $\mathrm{TiO}_{2}$ coating, inversely proportional to its amount. However, its beneficial effects on osteogenesis enhancement are prominent. It was proved that the $20 \% \mathrm{SrO}_{-} \mathrm{TiO}_{2}$ coating shows the best capacity of enhancing cellular proliferation and osteogenic differentiation, pointing out its potential application as an orthopaedic implant coating.

\section{Conflicts of interest}

There are no conflicts to declare.

\section{Acknowledgements}

The authors would like to acknowledge funding support from Shenzhen Science and Technology Research funding (JCYJ20150630114942256, JSGG20151030140325149, JCYJ20170413161800287), the Guangdong Provincial Science and Technology Project (2017A010103014) and National Natural Science Foundation (31700835). The authors also want to thank the final support from the Shenzhen Peacock Innovation Team (Grant 110811003586331).

\section{References}

1 C. Andreini, I. Bertini, G. Cavallaro, G. L. Holliday and J. M. Thornton, J. Biol. Inorg Chem., 2008, 13, 1205-1218.

2 A. Budimir, Acta Pharm., 2011, 61, 1-14.

3 V. Mouriño, J. P. Cattalini and A. R. Boccaccini, J. R. Soc., Interface, 2012, 9, 401-419.

4 N. A. T. Hamdy, Rheumatology, 2009, 48, 9-13.

5 H. Hu, W. Zhang, Y. Qiao, X. Jiang, X. Liu and C. Ding, Acta Biomater., 2012, 8, 904-915.

6 Z. Chen, X. Mao, L. Tan, T. Friis, C. Wu, R. Crawford and Y. Xiao, Biomaterials, 2014, 35, 8553-8565.
7 N. J. Lakhkar, I. H. Lee, H. W. Kim, V. Salih, I. B. Wall and J. C. Knowles, Adv. Drug Delivery Rev., 2013, 65, 405-420.

8 Z. Saidak and P. J. Marie, Pharmacol. Ther., 2012, 136, 216226.

9 L. Zhao, H. Wang, K. Huo, X. Zhang, W. Wang, Y. Zhang, Z. Wu and P. K. Chu, Biomaterials, 2013, 34, 19-29.

10 J. W. Park, H. K. Kim, Y. J. Kim, J. H. Jang, H. Song and T. Hanawa, Acta Biomater., 2010, 6, 2843-2851.

11 M. Long and H. J. Rack, Biomaterials, 1998, 19, 1621-1639.

12 W. Yang, X. Xi, Y. Si, S. Huang, J. Wang and K. Cai, Acta Biomater., 2014, 10, 4525-4536.

13 L. L. Guéhennec, A. Soueidan, P. Layrolle and Y. Amouriq, Dent. Mater., 2007, 23, 844-854.

14 H. Schliephake and D. Scharnweber, J. Mater. Chem., 2008, 18, 2404-2414.

15 J. W. Park, H. K. Kim, Y. J. Kim, J. H. Jang, H. Song and T. Hanawa, Acta Biomater., 2010, 6, 2843-2851.

16 W. Zhang, G. Wang, Y. Liu, X. Zhao, D. Zou, C. Zhu, Y. Jin, Q. Huang, J. Sun, X. Liu, X. Jiang and H. Zreiqat, Biomaterials, 2013, 34, 3184-3195.

17 C. Wu, Y. Ramaswamy, D. Kwik and H. Zreiqat, Biomaterials, 2007, 28, 3171-3181.

18 O. Z. Andersen, V. Offermanns, M. Sillassen, K. P. Almtoft, I. H. Andersen, S. Sørensen, C. S. Jeppesen, D. C. E. Kraft, J. Bøttiger, M. Rasse, F. Kloss and M. Foss, Biomaterials, 2013, 34, 5883-5890.

19 J. Lao, J. M. Nedelec and E. Jallot, J. Mater. Chem., 2009, 19, 2940-2949.

20 Y. Dang, L. Zhang, W. Song, B. Chang, T. Han, Y. Zhang and L. Zhao, Int. J. Nanomed., 2016, 11, 1003-1011.

21 H. Zreiqat, Y. Ramaswamy, C. Wu, A. Paschalidis, Z. Lu, B. James, O. Birke, M. McDonald, D. Little and C. R. Dunstan, Biomaterials, 2010, 31, 3175-3184.

22 K. Søballe and S. Overgaard, J Bone Joint Surg Br, 1996, 78, 689-691.

23 T. Kokubo and H. Takadama, Biomaterials, 2006, 27, 29072915.

24 M. Stern, Corrosion, 1958, 14, 60-64.

25 G. Wang, Z. Lu, D. Dwarte and H. Zreiqat, Mater. Sci. Eng., C, 2012, 32, 1818-1826.

26 P. M. Natishan, E. Mccafferty, G. K. Hubler and J. E. Soc, J. Electrochem. Soc., 1988, 135, 321.

27 M. Kosmulski, J. Colloid Interface Sci., 2009, 337, 439-448.

28 M. Kosmulski, J. Colloid Interface Sci., 2011, 353, 1-15.

29 M. Kosmulski, J. Colloid Interface Sci., 2014, 426, 209-212.

30 C. Capuccini, P. Torricelli, E. Boanini, M. Gazzano, R. Giardino and A. Bigi, J. Biomed. Mater. Res., Part A, 2009, 89, 594-600.

31 S. D. Newman, N. Lotfibakhshaiesh, M. O'Donnell, X. F. Walboomers, N. Horwood, J. A. Jansen, A. A. Amis, J. P. Cobb, M. M. Stevens, M. O. Donnell, X. F. Walboomers, N. Horwood, J. A. Jansen, A. A. Amis, J. P. Cobb and M. M. Stevens, Tissue Eng., Part A, 2014, 20, 1850-1857.

32 L. Li, X. Lu, Y. Meng and C. M. Weyant, J. Mater. Sci.: Mater. Med., 2012, 23, 2359-2368. 
33 X. Wang, Z. Gu, B. Jiang, L. Li and X. Yu, Biomater. Sci., 2016, 4, 678-688.

34 S. Omar, F. Repp, P. M. Desimone, R. Weinkamer, W. Wagermaier, S. Ceré and J. Ballarre, J. Non-Cryst. Solids, 2015, 425, 1-10.

35 D. Wu, F. Mao, Z. Yang, S. Wang and Z. Zhou, Mater. Sci. Semicond. Process., 2014, 23, 72-77.

36 A. Alem and H. Sarpoolaky, Solid State Sci., 2010, 12, 14691472.

37 G. Wang, X. Zhao, M. Möller and S. E. Moya, ACS Appl. Mater. Interfaces, 2015, 7, 23412-23417.
38 J. Wang, J. Ge, H. Hou, M. Wang, G. Liu, G. Qiao and Y. Wang, Appl. Surf. Sci., 2017, 422, 970-974.

39 V. Sollazzo, F. Pezzetti, A. Scarano, A. Piattelli, L. Massari, G. Brunelli and F. Carinci, J Craniofac Surg, 2007, 18, 806810.

40 P. J. Marie, P. Ammann, G. Boivin and C. Rey, Calcif. Tissue Int., 2001, 69, 121-129.

41 A. Hoppe, N. S. Güldal and A. R. Boccaccini, Biomaterials, 2011, 32, 2757-2774. 